\begin{abstract}
Iranica
Abstracta Iranica Revue bibliographique pour le domaine irano-aryen

Volume 32-33 | 2013

Comptes rendus des publications de 2009-2010
\end{abstract}

\title{
Anne Marie Carstens. The Labraunda Sphinxes
}

\section{Astrid Nunn}

\section{OpenEdition}

Journals

Édition électronique

URL : http://journals.openedition.org/abstractairanica/40221

DOI : 10.4000/abstractairanica.40221

ISSN : 1961-960X

Éditeur :

CNRS (UMR 7528 Mondes iraniens et indiens), Éditions de l'IFRI

Édition imprimée

Date de publication : 1 décembre 2013

ISSN : 0240-8910

\section{Référence électronique}

Astrid Nunn, «Anne Marie Carstens. The Labraunda Sphinxes », Abstracta Iranica [En ligne], Volume 32-33 | 2013, document 48, mis en ligne le 01 juillet 2016, consulté le 26 septembre 2020. URL : http:// journals.openedition.org/abstractairanica/40221 ; DOI : https://doi.org/10.4000/abstractairanica. 40221

Ce document a été généré automatiquement le 26 septembre 2020.

Tous droits réservés 


\title{
Anne Marie Carstens. The Labraunda Sphinxes
}

\author{
Astrid Nunn
}

\section{RÉFÉRENCE}

Anne Marie Carstens. «The Labraunda Sphinxes », in : Jens Nieling, Ellen Rehm, eds., Achaemenid impact in the Black Sea. Communication of powers. Aarhus, Aarhus University Press, 2010, p. 41-46. (Black Sea Studies, vol. 11).

1 L'A. replace les sphinx de Labraunda dans un contexte local et suggère qu'ils évoquaient le dieu Zeus Labraundos. La fonction palatiale des "bâtiments » de Labraunda n'en n'est que renforcée. Les sphinx, qui leur servaient d'acrotères, évoquaient ainsi tant la protection divine locale que les palais impériaux de Perse.

\section{AUTEURS}

ASTRID NUNN

Université de Munich 